\title{
Determinants of Internet Buying Behavior in India
}

\author{
Ruchi Nayyar \\ IILM Institute of Management Education \\ S. L Gupta \\ Birla Institute of Technology (Deemed Univ.)
}

\begin{abstract}
Internet penetration in India has become more widespread on account of easy payment options, reduced hardware prices, faster and cost effective internet communication, and reliable technology. Internet applications such as emailing, e-banking, e-gaming, travel and entertainment bookings have become part and parcel of the growing tech-savvy population in India. Although new business models focusing on e-retailing are providing exciting services to satisfy e-consumers' demands, the Indian internet retail market is far behind its expected potential. It therefore becomes imperative to assess the important determinants of internet buying behavior. There has been a very limited research to study the internet shopping behavior and factors responsible for determining online purchase intentions in India. The aim of this research is to provide a view of the various demographic and psychographic factors influencing consumer's willingness to purchase online. A new model based on Technology Acceptance Model (TAM) has been developed for the purpose of this research which incorporates consumer demographic factors and Perceived risk along with other TAM variables to explain the consumer acceptance of online shopping. The findings are expected to hold value for internet retailers as these are the simplest segmenting descriptors which will guide them in generating more effective business strategies for their organizations. Overall, this study seeks to provide productive insights into the factors determining the prospects of internet retailing in the country.
\end{abstract}

Keywords: Internet retailing, Technology Adaptation Model, B2C Ecommerce, demography, Perceived risk

\section{Introduction}

Internet has made a significant contribution to our lifestyles on account of its abundance and diversity of information. Its penetration is rising markedly in India which has fuelled the growth of e-commerce in the economy. The term e-commerce or electronic commerce refers to shopping on the web. It incorporates a lot of other activities such as B2B transactions, and various internal processes that companies use to support their buying, selling, hiring and planning. In terms of magnitude, e-commerce market has grown from 8147 crores in 2007 to 31598 crores by the end of year 2010 (IAMAI, 2011). Broadband connectivity and increased usage of credit cards have provided a favorable infrastructure for the growth of online shopping 
in India. Continued liberalization in the telecom sector has shown positive effects in the past few years. The Indian Telecom policy recognized the convergence of different media and permitted direct inter-connectivity amongst various service providers. This has paved the way to internet retailing which has become one of the most innovative and challenging contributions to the retail industry. It offers consumers an additional channel for information, service and purchasing along with additional benefits of choice, convenience and cost savings. Global online retailing has gained a significant share in overall retail sales over the past two decades.

B2C E-commerce has become a lucrative platform for e-marketers to attract potential e-buyers in India. On account of its diversity in culture, language and heritage, India can offer a favorable platform for innovative e-commerce based technologies. However, in comparison to wider acceptance of $\mathrm{B} 2 \mathrm{C}$ retail in developed economies, internet retailing is still in its nascent stages in India. Indian consumers do not seem to be overly enthusiastic about online purchasing. Delayed shipping, non favorable return policies and complicated cancellation processes seem to be some of the key factors that abstain potential customers to shop online. Owing to their age, gender, education, occupation and cultural instincts, the consumer buying behavior in India is still traditional. Indians prefer to have a feel of the product and spend time in buying. Lack of physical touch and inspection, security and privacy concerns are plaguing the growth of this market. Customers rely on purchasing familiar brands in order to reduce the risks associated with their purchase. Privacy concerns have dampened the online consumer enthusiasm in India. There are a number of issues related to security and transaction frauds. High occurrences of failed payments deter the customer to revisit portals for shopping. With regard to the future of etailing in India, the views are divergent. Many experts believe that the future of internet business is very promising and expect its exponential growth in the coming times. Overall, Indian etail business is a rich business waiting to be exploited! It has become imperative for online retailers to understand the attitudes and preferences of the internet consumers and devise appropriate business strategies to gain competitive advantage. This study aims at improving the understanding of online consumer behavior by investigating various factors affecting intention to purchase online.

\section{Literature Review}

The Technology Adoption Model (TAM), on account of its robustness, parsimony and explanatory powers, is believed to be the most effective model for understanding the adoption of technology. (Davis, Bagozzi, and Warshaw, 1989; Venkatesh and Davis, 2000; Venkatesh et al., 2003). TAM has been exceedingly successful in explaining technology adoption behavior and has been utilized by many researchers to understand consumers' online purchase behavior as well. However, investigations to understand the Indian consumer online behavior are still minimal. Therefore, this study aims to develop and test a modified TAM that is appropriate for the Indian context.

\section{Technology Acceptance Model: A Theoretical Basis}

TAM provides an explanation of the determinants of computer acceptance that is general, capable of explaining user behavior across a broad range of end-user computing technologies and user populations (Davis et. al., 1989). TAM is based on the Theory of Reasoned Action (Fishbein and Ajzen, 1975) which suggests that attitude and intention drive an individual's 
social behavior. This means that within available time and context, individuals' behavior vary with respect to their intentions. TAM posits that the two primary antecedent variables determining attitude to adopt an information system include perceived usefulness and perceived ease of use. TAM specifies the causal relationships between system design features, perceived usefulness, perceived ease of use, attitude toward using, and actual usage behavior. In general, TAM provides an informative depiction of the mechanisms by which design choices influence user acceptance. It therefore helps in forecasting and evaluating user acceptance of technology related products and services. A number of researchers have used the constructs of perceived usefulness, perceived ease-of-use, and subjective norm to explain technology usage/acceptance for a variety of information systems such as online purchasing. The following TAM model depicts the conceptual model of this study.

Figure 1: Technology Acceptance Model (TAM)

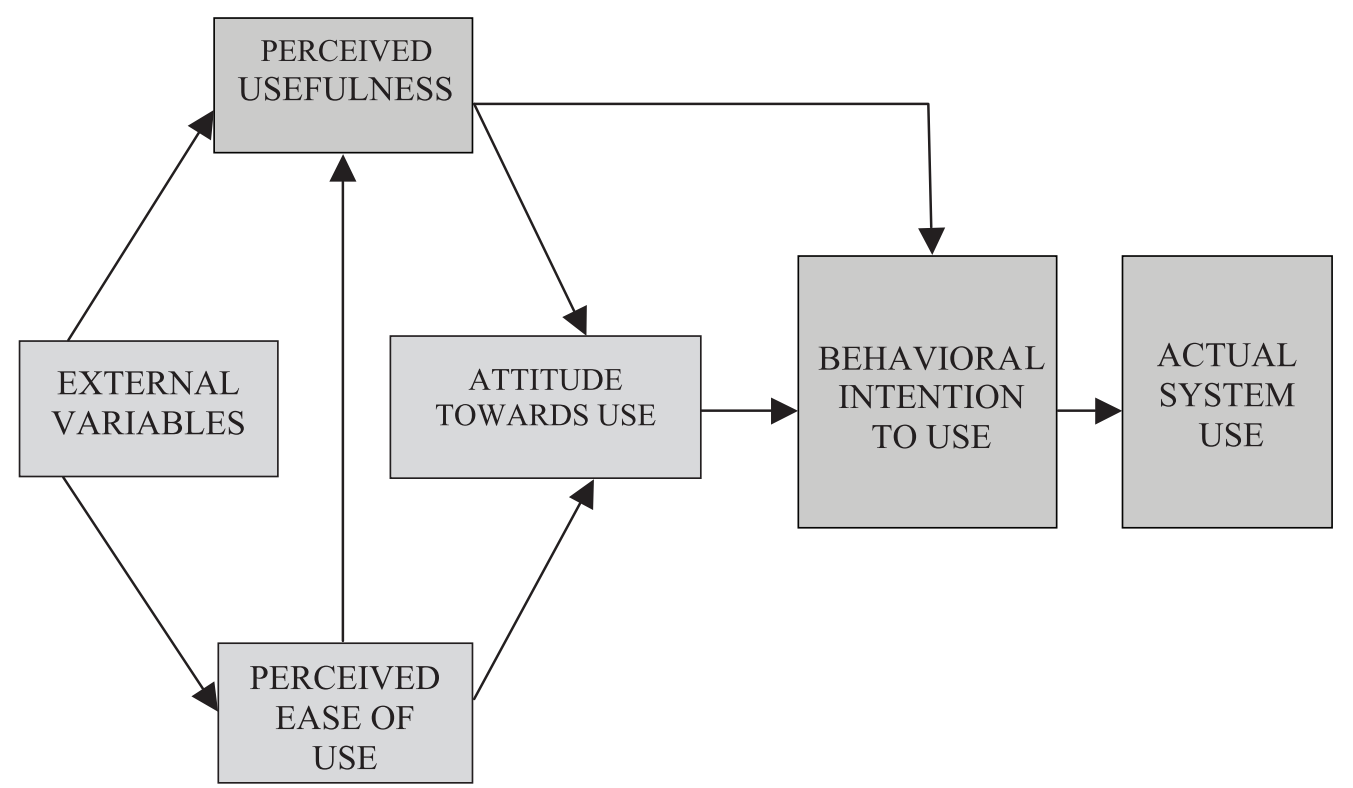

Perceived usefulness refers to the degree to which a person believes that using the new technology will improve his or her performance or productivity (Davis, Bagozzi and Warshaw, 1989 and 1985).

Perceived ease of use on the other hand, indicates how the users perceive the ease of using the technology. It is defined as the degree to which a person believes that using a particular system would be free from effort (Davis, Bagozzi and Warshaw, 1989).

Behavioral Intention is defined as the degree to which a person has formulated conscious plans to perform or not perform some specific future behavior (Davis and Warshaw, 1985). It forms a strong predictor of actual system use. TAM posits that Behavioral Intention is a strong determinant of system use and is determined by Perceived Usefulness and Perceived Ease of Use. Based on TAM, following hypotheses have been formulated. 
H1: Perceived usefulness is related to Behavioral Intention in an online shopping environment. $\mathrm{H} 2$ : Perceived ease of use is related to Behavioral Intention in an online shopping environment.

TAM also posits that perceived ease of use and perceived usefulness are closely linked. If applied to the context of internet shopping, if an internet user perceives internet purchase as hassle free, he/she will develop a tendency to perceive it as useful. Thus,

H3: Perceived ease of use is related to Perceived Usefulness in an online shopping environment.

\section{Online Shopping Orientation}

One of the setbacks of TAM is that it treats online purchasing at the outset of the technology. On account of its emphasis only on the cognitive determinants of IT use intention; TAM cannot be applied to the adoption of internet technology for purchase purpose. This research argues that Perceived risk and demography are critical factors forming the potential e-shopper's intention on the shopping orientation of an e-shopper.

Perceived risk is defined as a functional or psychosocial risk a consumer feels he or she is taking when purchasing a product. Bauer (1960) has defined perceived risk as a combination of uncertainty plus seriousness of outcome involved. Peter \& Ryan (1976) have defined perceived risk as the expectation of losses associated with purchase and acts as an inhibitor to purchase behavior. It's observed that the perceived risk in e-commerce is greater than that of commerce at brick-and-mortar retail stores. Credit card security, lack of touch and feel, concerns related to return the item, and transaction security have prevented consumers against purchasing online (Bellman et al, 1999). Thus, the likelihood of purchasing on the Internet decreases with increase in consumers' perceptions of risk. Perceived risk is extremely important to understand the online shopping behavior because it impacts other consumer perceptions including perceived ease of use and perceived usefulness (Lee et al., 2001). In an ecommerce environment, the combination of uncertainty (likelihood of loss) and danger (cost of the loss) which form the two components of the perceived risk have a negative influence on perceived ease of use and adoption (Chen et al, 2006).Therefore higher the perceived risk, the lower the perceived value of the system . Many previous researches have pointed out that ease of use reduces the uncertainty and risk of system use (Fetherman and Pavlou, 2003). This indicates that if a consumer perceives that internet services are easy to use then he would also perceive that other services related to the internet will perform well and he would be more willing to adopt them. Thus,

H4: Perceived ease of use of Internet purchase has a negative influence on internet shoppers' Perceived purchase risk.

\section{Individual Differences}

Demography (age, gender, profession, education etc) affect how technology is used (Zmud, 1989; Assael, 1981). Hence, it's important to study the impact of demographic variables on online shopping. The socio-economic status of early adopters is higher than late adopters (Rogers, 1995). Men and women also differ in their attitudes toward e-shopping. Traditional Indian women regard shopping as a social release. In most of the families, women are the chief decision makers (Dholakia, 1999). Men are more motivated toward utilitarian benefits of products and give lesser importance to social relations and personal contacts (Steenkamp et al., 
1999). Many women perceive shopping as an entertainment channel to socialize and interact with other consumers. Hence, they get more satisfied purchasing from brick establishments rather than from online stores. Men lay more emphasis on hassle free purchases in the comfort of their homes or workplaces and mind less on the hedonistic benefits of store shopping. Hence their overall positive attitude towards internet shopping is higher compared to the fairer sex (Teo, 2001). Unlike women, men are less motivated by inspirational and stimulating effects of brick and mortar purchases. Thus,

H5: Gender affects intention to purchase online.

Needs, interests and resources vary with age. In contrast to a tech-savvy younger generation, the older generation is more satisfied with conventional shopping methods (May and Greyser, 1989). There is less time constraint for the older community, thus tend to socialize more through traditional shopping medium. Younger generation has always exhibited a positive disposition towards adoption of a new innovation (Schiffman and Kanuk, 2003). Younger people are more ready to embrace innovative technology compared to the older group. The early adopters of internet technology are typically younger in age primarily on account of its utilitarian and hedonistic benefits (Bordeaux et al., 2002).It is also found that the younger generation is less concerned about the security and reliability aspects of internet technology ( Fogg et al., 2000). Computers intimidate many elderly (Eastman and Iyer, 2004) leading to reduced internet activities amongst older population. Thus,

H6: Age affects intentions to purchase online.

Educated and higher income group patronize internet retailing more than lower educated and lesser income group (Cunningham and Cunningham, 1973). Educated people make good innovators and early adopters of new technology (Teo, 2001; Zhao et al., 2002; Dillon and Reif, 2004). Less educated people tend to exhibit a higher degree of computer anxiety towards computer technology (Parasuram and Igbaria, 1989). Hence, their negativity towards electronic retailing as a direct form of retailing is inevitable. Thus,

H7: Education affects intention to purchase online.

A large income encourages people to conduct more internet shopping (Fogg et al., 2001). People at higher positions in their organizations embrace new and innovative technology faster compared to those at lower positions in their organizations. Higher the educational level, income, and occupation, higher would be the perception of internet retailing (Cunningham and Cunningham, 1973; Reynolds, 1974; Wotruba and Pribova, 1995). Many earlier researches have revealed that most of the internet shoppers are men, earning high incomes and owning a university education (Dholakia and Usitalo, 2002; Li et al., 1999; Vrechopoulos et al., 2001). Thus,

H8: Income affects intention to purchase online.

H9: Position in the organization affects intention to purchase online.

\section{Research Framework}


The following figure illustrates the modified TAM developed for this study to understand the determinants of internet buying behavior in the Indian context. As mentioned above, the attitude construct is removed from this research model while perceived risk and demography have been included.

Figure 2: Research Model

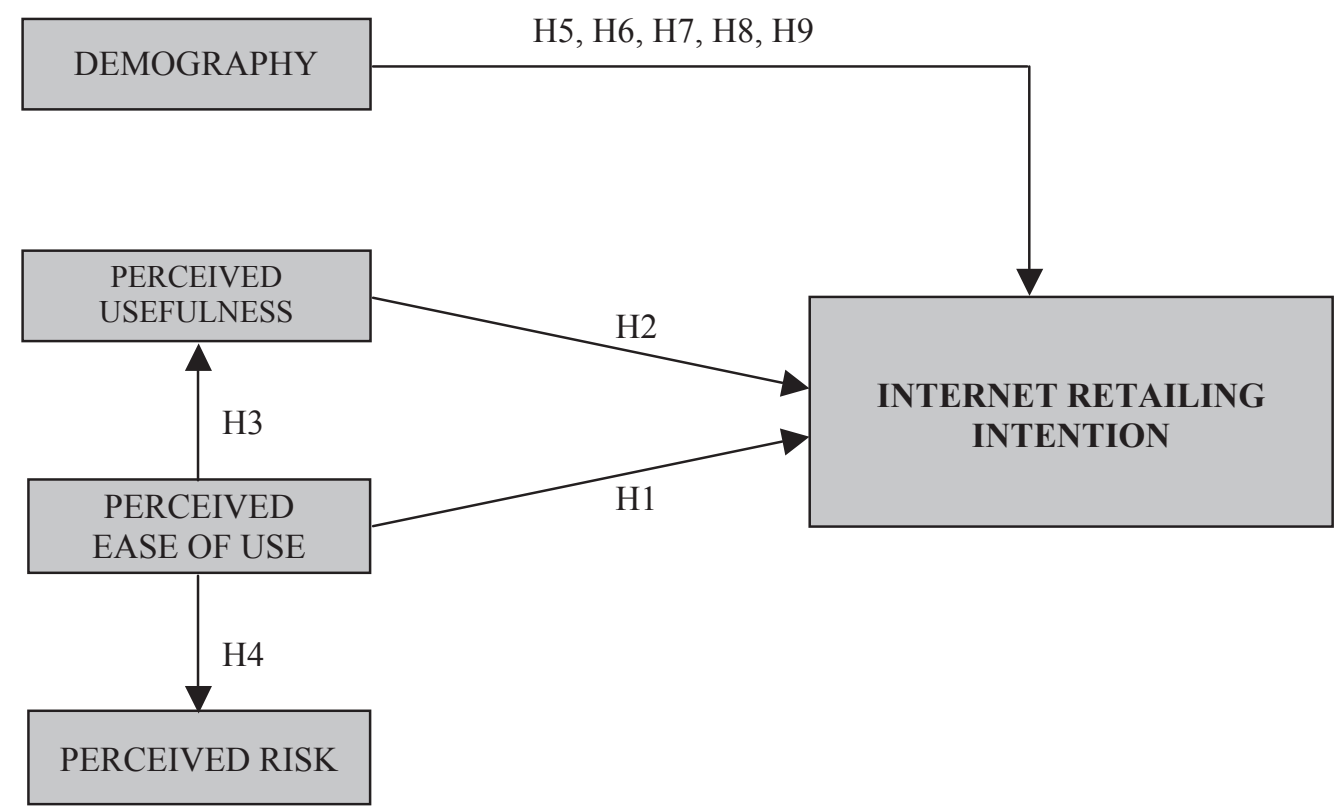

\section{Research Methodology}

This study involves non-probabilistic convenience sampling. 500 customers were selected throughout the urban and semi urbanized locations of India. Questionnaires were distributed both manually and electronically through web. Quantitative data was collected from a selfadministered questionnaire. Utmost care was undertaken to ensure that there is insignificant sampling error and the results of the sample study can be applied, in general, for the universe with a reasonable level of confidence. The study used a variety of questions to find out complete information about the topic under research. Apart from dichotomous and multiple-choice questions, the questionnaire also included statements which the respondents were required to rate on the basis of different scales like the Likert scale and rating scale. The research instrument constituted a 5-section questionnaire that was modified from various resources in order to gather information related to demographics, perceived usefulness, perceived ease of use, perceived risk and behavioral intention to purchase online. Samples of measures and variables are shown below: 
Table I: Questionnaire preparation

\begin{tabular}{|l|l|l|}
\hline Section & Sample Questions & Source \\
\hline $\begin{array}{l}\text { Perceived } \\
\text { Usefulness }\end{array}$ & $\begin{array}{l}\text { I like internet shopping as it offers me round the } \\
\text { clock shopping } \\
\text { I like browsing online to preview products before } \\
\text { purchasing }\end{array}$ & $\begin{array}{l}\text { Adapted based on } \\
\text { Davis (1989) }\end{array}$ \\
\hline $\begin{array}{l}\text { Perceived Ease of I feel internet shopping is a fun filled experience } \\
\text { Use } \\
\text { I feel better quality products are offered on the } \\
\text { Internet feel better quality products are offered on the } \\
\text { internet }\end{array}$ & $\begin{array}{l}\text { Adapted based on } \\
\text { Davis (1989) }\end{array}$ \\
\hline Perceived Risk & $\begin{array}{l}\text { I find public knowledge of my purchases risky } \\
\text { I feel internet retailers are not trustworthy }\end{array}$ & $\begin{array}{l}\text { Baur (1960), Bellman } \\
\text { et al. (1989), Chen et } \\
\text { al. (2006) }\end{array}$ \\
\hline $\begin{array}{l}\text { B e h a v i o r a 1 1 feel shopping in the local markets is too time } \\
\text { consuming and problematic } \\
\text { I find internet shopping quite easy }\end{array}$ & $\begin{array}{l}\text { Adapted based on } \\
\text { Ajzen and Fishbein } \\
(1980) \text { Davis and } \\
\text { Warshaw (1985) }\end{array}$ \\
\hline
\end{tabular}

Pre-testing of the research instrument was carried out on a sample of 40 Management students from a reputed Indian Management Institute. Descriptive and frequency testing was employed on the quantitative data. Moreover, Factor analysis technique was deployed for identifying the structure of a set of variables and for data reduction (Hair et al., 1998).

\section{Data Analysis and Results}

Most of the respondents are males (66\%). The highest percentage of the respondents is salaried $(65.9 \%)$, with $48.9 \%$ falling in the salary bracket of Rs. 2 to 4 lakhs per annum. The given sample comprises of internet users aged 15 and more. A larger percentage of the sample $(79 \%)$ belongs to the age group of 22-29 years. While the least representative group of respondents is of age group of 40-49 years and above, there is no respondent aged 60 or above. This could be on account of lack of use and familiarity of computer technology. Finally $73 \%$ are postgraduates and $42 \%$ are graduates. Respondents were asked to pick up their recent online purchase. $74 \%$ have utilized internet to book tickets. Travel related purchases have totally dominated web shopping in the country. 55\% respondents believe convenience as the reason influencing online purchase. Besides, privacy and security related issues are the chief stumbling blocks while making internet purchases.

R-type factor analysis is deployed to understand the structure of the psychographic variables. Metric variables chosen for the purpose of this research constituting a homogenous set of perceptions are found to be most suitable for conducting factor analysis. The output of factor analysis indicates that the first three components are explaining $66.2 \%$ of the total variance. Reliability of the multi-item scale for each dimension was measured using Cronbach alphas. The measure of reliability for 20 number items on a sample size of 500 was observed to be 0.5986 which is above the recommended minimum standard of social science based researches.

The italicised variables are related negatively to the dependent variable. Hence, these variables 
can be clubbed into group 'Perceived risk'. Although, Factor Analysis does not generate a new factor for Perceived risk, the values support H4; Perceived ease of use of Internet purchase has a negative influence on internet shopper's perceived Purchase risk.

Table II: Results of Factor Analysis

\begin{tabular}{|c|c|c|}
\hline Factor & Loading & Reliability \\
\hline Factor 1: Perceived Usefulness & & 0.63 \\
\hline $\begin{array}{l}\text { I like internet shopping as it offers me round the clock } \\
\text { shopping }\end{array}$ & 0.61 & \\
\hline I like browsing online to preview products before purchasing & 0.59 & \\
\hline $\begin{array}{l}\text { I think internet shopping offers better choices than local } \\
\text { store }\end{array}$ & 0.45 & \\
\hline $\begin{array}{l}\text { I think browsing on the internet saves a lot of my window } \\
\text { shopping time }\end{array}$ & 0.78 & \\
\hline Factor 2 : Perceived Ease of Use & & 0.75 \\
\hline I find internet shopping is a new experience & 0.43 & \\
\hline I find internet shopping is a fun filled experience & 0.58 & \\
\hline I feel better quality products are offered on the internet & 0.53 & \\
\hline $\begin{array}{l}\text { I get scared by identity thefts through credit cards while } \\
\text { purchasing online }\end{array}$ & -0.84 & \\
\hline I find public knowledge of my purchases risky & -0.72 & \\
\hline $\begin{array}{l}\text { Ifeel easy accessibility on computers threatens my credit } \\
\text { card details }\end{array}$ & -0.86 & \\
\hline Ifeel scared to buy things on internet & -0.8 & \\
\hline Ifeel internet retailers are not trustworthy & -0.76 & \\
\hline I like home delivery of products on online purchase & 0.88 & \\
\hline $\begin{array}{l}\text { I like online shopping to avoid problems at local shopping } \\
\text { centers }\end{array}$ & 0.82 & \\
\hline $\begin{array}{l}\text { I prefer online shopping to avoid driving and parking } \\
\text { hassles. }\end{array}$ & 0.83 & \\
\hline $\begin{array}{l}\text { I like shopping online in the comfort of my home and } \\
\text { surroundings }\end{array}$ & 0.85 & \\
\hline I like discounts and incentives schemes on the internet & 0.83 & \\
\hline Factor 3: Behavioral Intention & & 0.47 \\
\hline $\begin{array}{l}\text { I feel shopping in the local market is too time consuming } \\
\text { and problematic }\end{array}$ & -0.41 & \\
\hline I find internet shopping quite easy & -0.38 & \\
\hline $\begin{array}{l}\text { I like going through product reviews and recommendations } \\
\text { by other browsers }\end{array}$ & 0.58 & \\
\hline
\end{tabular}




\section{Regression Analysis}

The concern of our model is whether the variables have an influence as hypothesized. To serve this purpose, three multiple regression analysis (MRS) were conducted. The first is used to analyze the relationship between PU and BI, the second between PEU and PU and the third between PEU and PU.

Figure 3: Revised Model

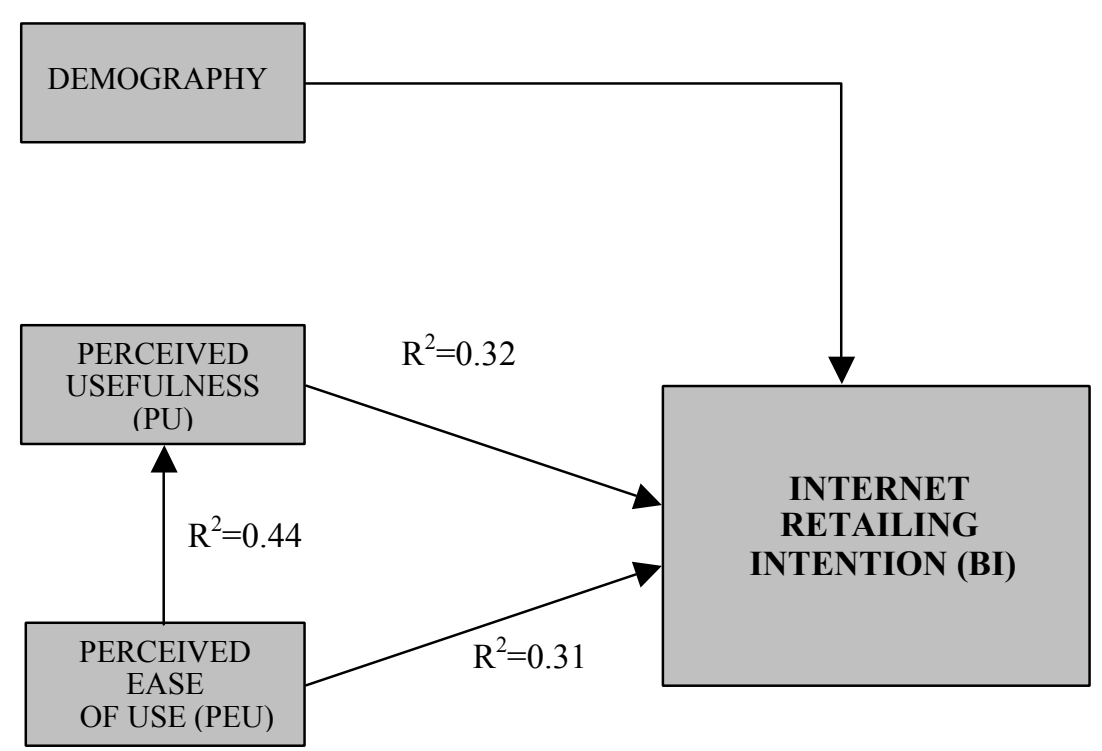

R2 values indicate presence of a strong relationship between PU and PEU. Therefore, H3 is supported. Between PU and BI, the relationship as indicated by the regression coefficients does not seem to be good. However, it appears that the hypothesis H2 is pointing in the right direction. Similarly, although the relationship between PEU and BI does not seem to be strong, but since the hypothesis is pointing in the right direction, $\mathrm{H} 1$ is accepted.

\section{Impact of Demography on Behavioral Intention}

In order to study the impact of demography on Behavioral Intention, the interval data constituting BI was first modified into nominal data incorporating only 2 options - intended to shop online and not intended to shop online. Thereafter, Chi- square test was used to identify whether given two discrete variables are in a relationship or are independent. Results indicate that gender $\left(\chi^{2}=29.642, \mathrm{p}=0.000\right)$, age $\left(\chi^{2}=18.387, \mathrm{p}=0.000\right)$, income $\left(\chi^{2}=34.491, \mathrm{p}=0.000\right)$ and position in the organization $\left(\chi^{2}=53.11, \mathrm{p}=0.000\right)$ affect intention to purchase online positively, whereas education $\left(\chi^{2}=4.626, p=0.099\right)$ is found to have no impact on internet purchase intention. 
Table III: Summary of results

\begin{tabular}{l|l}
\hline Hypothesis & $\begin{array}{l}\text { Accepted/ } \\
\text { Rejected }\end{array}$ \\
\hline H1 & Accepted \\
\hline H2 & Accepted \\
\hline H3 & Rejected \\
\hline H4 & Accepted \\
\hline H5 & Accepted \\
\hline H6 & Accepted \\
\hline H7 & Rejected \\
\hline H8 & Accepted \\
\hline H9 & Accepted \\
\hline
\end{tabular}

\section{Conclusions}

The results have displayed significant relationships between research variables. Perceived ease of use has a negative influence on perceived risk. Perceived ease of use is positively associated to perceived usefulness. The outcome of this research suggests that perceived ease of use and perceived usefulness are antecedents of intention to purchase online. However, results do not indicate a strong relationship between PEU-BI and PU-BI. This clearly shows that Indians are somewhat reluctant to transacting online. Indians look at shopping as an entertainment activity and consider visiting malls and brick and mortar outlets as an escape from their day-to-day routine. Other factors holding them back from online shopping include fear of identity and financial theft, product genuineness, lack of touch and feel, delivery time and fixed price format. It's imperative for online vendors to understand the factors that may influence the formation of consumer's behavioral intention toward online shopping. Increasing online brand presence may prove to be an effective solution. Most of the leading brands are either not present online or are present in a very non-friendly manner. Internet retailers can also increase their clientele by providing significant discounts across products. Attractive discounts by brands can act as a magnet in motivating consumers to buy online. Extensive market researches could enable online vendors to identify preferences of their major customer groups and adjust their website contexts accordingly. Latest technology can enable creation of attractive catalogues for offers and promotions. Easy going navigational features amalgamated with multiple payment options and running innovative customer reach programs could act as mascots for online retailers. Frequently personalized information and exclusively personalized website could diminish perceived risk to a large extent.

The findings of this study have revealed a higher number of male internet shoppers than females. The results are in consistence with the literature review. Men adopt computer technology much faster than females. In comparison to females, males are more prone to participate in internet activities predominantly emailing, information search or downloading and purchasing activities. Females exhibit a higher degree of computer nervousness and technostress than males. Age has also been found to have an influence on internet retailing adoption. Internet usage has not diffused uniformly amongst all age groups, hence the difference in attitude towards online 
purchase. Surprisingly, education has not shown any significant association to internet retailing. It should be noted, however, in the present study that respondents are sufficiently educated, falling in the category of graduates and above. They constitute the PC literate population with higher exposure and awareness of internet. Another plausible justification could be that internet; with its high degree of user friendliness makes differences in educational levels insignificant. Although, this population makes versatile use of various online applications such as emailing, messaging, online gaming, information research etc., but not internet retailing. This clearly indicates that online retailing is not the most appealing and convenient means of shopping amongst internet users in India. Annual household income affects internet retailing adoption. Higher income motivates more purchasing. Similar justification holds good for the positive association obtained between position in the organization and internet retailing adoption. Higher position in an organization indicates more awareness of modern technology and opportunities that increases higher online retailing prospects.

\section{Limitations of the research and Suggestions for future research}

Despite meeting the objective of the present research, a few limitations were identified in the course of this study. This research investigates the impact on internet retailing by various factors in Indian retail industry. Thus, the outcomes of this research are best suited to Indian e-commerce retail industry. These findings cannot be replicated to other nations owing to differences in terms of economy, culture and technology.

Though the sample size selected for this research is acceptable, a bigger sample size could have assessed behavioral and attitudinal perceptions in greater depth. Besides all respondents were internet savvy and sufficiently educated. Future research might examine the diverse internet users such as older, less internet savvy and less educated. Finally, this research is only confined to online shopping in India. Further research can be expanded to other shopping channels including phone shopping, catalog shopping or TV shopping.

\section{References}

Assael, Henry (1981), Consumer Behavior and Executive Action, Boston: Kent.

Bauer, R. "Consumer Behavior in Risk Taking and Information Handling in Consumer Behavior", D. Cox (ed.) Harvard University Press, Cambridge, Mass, 1967.

Bellman, S., Lohse, G., and Johnson, E. "Predictors of Online Buying Behavior". Communications of the ACM (42:12), 1999, pp. 32-38.

Bordeau, L., J. Chebat and C. Couturier (2002), "Internet consumer value of university students: E-mail versus Web users", Journal of Retailing and Consumer Services, Vol. 9, No. 2: 61-69.

Chen, Yueh-Yang; Yeh, Downing; Finger, Glen; Tsai, R.J and Sun, Pei-Chen (2006), "What drives a successful e-Learning? An empirical investigation of the critical factors influencing learner satisfaction", Volume 50, Issue 4.

Cunningham, I. and W. Cunningham (1973), "The urban in-home shopper: Socio-economic and attitudinal characteristics", Journal of Retailing, Vol. 49, No.1:42-57. 
Davis, Bagozzi, and Warshaw (1992), "Extrinsic and Intrinsic Motivation to Use Computers in the Workplace," Journal of Applied Social Psychology, 22 (14), 1111-32

Davis, F. D., Bagozzi, R.P. and Warshaw, Paul R. (1989). User Acceptance of Computer Technology: A Comparison of Two Theoretical Models. Management Science, 35(8), 982-1003.

Dholakia, R. (1999), "Going shopping: key determinants of shopping behaviors and motivations", International Journal of Retail and Distribution Management, Vol. 27, No. 4:.154-165.

Dholakia, R.; Usitalo, O. (2002)" "Switching to electronic stores: consumer characteristics and the perceptions of shopping benefits". International Journal of Retail and Distribution Management, 30 (10), p. 459-469.

Dillon, T.W., Reif, H.L. (2004), Factors influencing consumers' e-commerce commodity purchases. Information technology, Learning and Performance Journal, Vol. 22, No 2, Fall 2004, pp 1-12.

Fetherman, M.S and Pavlou, P.A (2003), "Predicting e-services adoption; Perceived risk facets perspective", International Journal of Human-Computer Studies, Volume 59, Issue 4, Pages 451-474

Fishbein, M., \& Ajzen, I. (1975). Belief, attitude, intention and behavior: an introduction to theory and research. Addison-Wesley, Reading, MA.

Fogg, B., Marshall, J., Laraki, O., Osipovich, A., Varma, C., Fang, N., Paul, J., Rangnekar, A., Shon, J., Swami, P. and Treinen, M. (2001). "What makes web sites credible? A report on a large quantitative study". Stanford University.

Hair, J.F., Anderson, R.E., Tatham, R.L. \& Black, W.C. (1998). Multivariate Data Analysis. New Jersey: Prentice Hall.

Lee, Younghwa; Kozar, Kenneth A.; and Larsen, Kai R.T (2003), “The Technology Acceptance Model: Past, Present, and Future". Communications of the Association for Information Systems: Vol. 12, Article 50.

Li, H., C. Kuo and M. Russell (1999), "The Impact of perceived Channel Utilities, Shopping Orientations, and demographics on the Consumer's Online Buying Behavior", Journal of Computer Mediated Communications, Vol.5, No.2.

May, E. and S. Greyser (1989), "From-home Shopping: Where is It Leading?" in Pellegrini, L. Reddy, S., Retail and Marketing Channels-Economic and Marketing Perspectives on Producer-Distributor Relationships.

Parasuraman, S. and Igbaria, M. (1990), "An examination of gender differences in the determinants of computer anxiety and attitudes towards microcomputers among managers", International Journal of Man-Machine Studies, Vol. 32, pp. 327-40.

Peter, J., Ryan, M. .An Investigation of Perceived Risk at the Brand Level,. Journal of Marketing Research, 13, May 1976, pp. 184-188.

Reynolds, F.D (1974), “An Analysis of Catalog Buying Behavior”, Journal of Marketing, 38(July), 4751. 
Rogers, E.M (1995), "Diffusion of Preventive Innovations", Addictive Behaviors, Volume 26, Issue 6, Pages 989-993.x

Schiffman, L. and L. Kanuk (2003), Consumer Behavior (8th Ed.). Prentice Hall: New Jersey.

Steenkamp, J., F. Hofstede and M. Wedel (1999), "A cross-national investigation into the individual and national antecedents of consumer innovativeness", Journal of Marketing, Vol. 63:55-69, April 1999

Teo, T.S.H. (2001). "Demographic and Motivation Variables Associated with The internet Usage Activities". The internet research: electronic network applications and policy, Vol 11, No 2, pp $125-137$

Venkatesh, V. \& Davis, F. D. (2000). "A theoretical extension of the technology acceptance model: four longitudinal field studies”. Management Science, 46 (2), 186-204.

Venkatesh, V. \& Morris, M. (2000). "Why don't men ever stop to ask for directions? Gender, social influence and their role in technology acceptance and usage behavior". MIS Quarterly, 24(1), 115-139.

Vrechopoulos, A., G. Siomkos and G. Doukidis (2001), "Internet shopping adoption by Greek consumers". European Journal of Innovation Management, Vol.4, and No.3:142-152.

Wotruba, T.; Pribova, M. (1995): "Direct selling in an emerging market economy: a comparison of central Europe with the U.S". In T. Wotruba: Proceedings of the international academic symposium on direct selling in central and Eastern Europe, pp. 87-193. Direct Selling Education Foundation: Washington, DC

Zhao, Z.J. and Gutierrez, J.A. (2002). "Customer service factors influencing the internet shopping in New Zealand". Issues in informing science and information technology, University of Auckland, Auckland, New Zealand.

Zmud, R.W (1979), "Individual Differences and MIS Success”, Management Science, Vol. 25, No. 10, pp. 966-969. 